\title{
Reaction mechanisms of potassium oxysalts based energetic composites
}

Wenbo Zhou, Jeffery B. DeLisio, Xizheng Wang, Michael R. Zachariah* 


\section{ABSTRACT}

16 Ignition temperature is a simple and important parameter that pertains to both the practical 17 aspects of thermite usage as well as a key to exploring reaction mechanisms. In this study, nine 18 aluminum-fueled oxysalt-containing thermites including $\mathrm{K}_{2} \mathrm{~S}_{2} \mathrm{O}_{8}, \mathrm{~K}_{2} \mathrm{SO}_{4}, \mathrm{KIO}_{4}, \mathrm{KIO}_{3}, \mathrm{KClO}_{4}$, $19 \mathrm{KClO}_{3}, \mathrm{KBrO}_{3}, \mathrm{KNO}_{3}$ and $\mathrm{K}_{3} \mathrm{PO}_{4}$, were investigated. Results from combustion cell tests show 20 that these thermites can be divided into two groups, with the reactive thermites (e.g., $\mathrm{Al}-\mathrm{K}_{2} \mathrm{~S}_{2} \mathrm{O}_{8}$ ) 21 generating $\sim 10 \times$ higher of pressure and $\sim 10 \times$ shorter of burn time than the less reactive thermites 22 in the aforementioned list (e.g., $\left.\mathrm{Al}-\mathrm{K}_{2} \mathrm{SO}_{4}\right)$. Thermal decomposition analysis of these oxysalts at 23 both slow and fast heating rates $\left(0.17 \mathrm{~K} / \mathrm{s}\right.$ v.s. $\left.10^{5} \mathrm{~K} / \mathrm{s}\right)$ demonstrates that these oxysalts have a 24 wide range of oxygen release and melting temperatures. On the other hand, the ignition 25 temperatures of the reactive thermites (in Ar and air) are consistent with the temperature of 26 polymorphic phase change of alumina (close to the melting point of $\mathrm{Al}$ ), indicating that the 27 limiting initiation step of these thermites is the acceleration of outward diffusion flux of Al. In 28 addition, the ignition temperatures of these reactive thermites in vacuum are much higher than 29 those in Ar, suggesting that ignition is based on the interaction between outwardly diffused Al, 30 and generated gas phase $\mathrm{O}_{2}$. In contrast, the ignition temperatures of the two less reactive 31 thermites are insensitive to pressure. They ignite at temperatures much higher than the melting 32 point of $\mathrm{Al}$, although lower than the decomposition temperature of the corresponding oxysalts, 33 indicating a condensed phase reaction mechanism. Finally, by employing carbon as a non34 melting, non-oxide coated fuel, we found an essentially direct correlation between the oxygen 35 release temperature and the ignition temperature.

\section{KEYWORDS}

37 Ignition temperature; Oxygen release; Melting; Oxysalts; Reaction mechanism 


\section{Introduction}

39 Since the thermite reaction was first named by Goldschmidt in 1908 [1], the concept

40 has been currently broadened to a variety of exothermic reactions involving a metal 41 reacting with an oxide (metal or non-metal) or an oxysalt [2-5]. Due to its extremely high 42 energy density, the thermite system has been employed in a wide array of applications in 43 the pyrotechnic, metallurgical, and ceramic industries [2-5], which has prompted studies 44 to improve their utilization by tailoring their combustion and ignition behaviours [6-10]. 45 The latter property also involves practical safety concerns related to the large-scale 46 industrial use $[11,12]$. One important research direction is to improve the ignitibility of 47 thermites, which is affected by many factors (contact area, chemical composition, 48 hygroscopicity, etc.). The most common method is by increasing the contact area between 49 the fuel and oxidizer, which can reduce the diffusion distance of reactive species to permit 50 ignition at lower temperatures [13-17]. This higher degree of intimacy can be achieved by 51 either decreasing the particle size [14-17], better mixing [13,18,19], or increasing the 52 particle porosity [20].

53 For the most common aluminum-fueled thermite systems, ignition was proposed to be 54 initiated by a solid-state reaction [21]. Subsequent reaction requires movement of reactive 55 species towards each other, although the nature of this movement is subject to 56 considerable debate [22-28]. However, it was previously reported that the prerequisite for 57 ignition is the availability of molten aluminium [21,29]. Based on this speculation, 58 ignition temperatures for a plethora of thermites should be around the melting point of 59 aluminum. However, a recent study by Jian et al. [30] shows that there can be large 60 differences in ignition temperatures among different nano-thermite formulations 
61 involving aluminum and metal oxides. For instance, some formulations (e.g., $\mathrm{Al}^{-} \mathrm{Bi}_{2} \mathrm{O}_{3}$, $62 \mathrm{Al}_{-\mathrm{SnO}_{2}}$ ) have ignition temperatures lower than both the melting point of aluminum, and 63 the decomposition temperatures of oxidizers, suggesting another condensed phase 64 reaction mechanism that is not governed by melted aluminium [31]. Similarly, Dean et 65 al.[32] examined another nano-thermite formulation (Al-NiO), which produces minimal 66 gas upon ignition, with a much lower ignition temperature $\left(\sim 400{ }^{\circ} \mathrm{C}\right)$ [33] than either the 67 melting temperature of Al or the decomposition temperature of NiO. Sullivan et al. [34] 68 implemented in situ rapid heating microscopy to monitor the nano-thermite reaction of $69 \mathrm{Al}^{-} \mathrm{WO}_{3}$ and found a reactive sintering phenomenon [35] in which no gas was released, 70 and the reactants deformed to maximize intimate surface contact. While several thermites 71 appear to react via this condensed phase route [32-37], ignition temperatures of some 72 other formulations may exceed the decomposition temperature of metal oxides, 73 suggesting a different reaction mechanism [30].

74 To date, discussions on ignition mechanism of thermites have been limited to 75 formulations containing various metal oxides $\left(\mathrm{CuO}, \mathrm{Fe}_{2} \mathrm{O}_{3}\right.$, etc.), whereas the ignition 76 mechanism for thermite formulations containing oxysalts (nitrates [38-40], (per)chlorates 77 [41-44], (per)iodates [45-47], etc.) have not been explicitly studied from a mechanistic 78 standpoint. Typically, Al-oxysalt thermites exhibit lower ignition temperatures and higher 79 reaction rates $[44,47-49]$, which are associated with the low oxygen release temperatures 80 of the corresponding oxysalts. An initial exothermic decomposition of some oxysalts 81 during heating may also contribute to the low ignition temperature [41,47]. Recently, a 82 new formulation based on persulfates was found to be more reactive when compared to 83 other oxysalts [50]. The superiority of oxysalts in thermite performance can likely be 
84 attributed to the higher oxygen content, and the lower bond energy of the nonmetal85 oxygen pair in oxysalts when compared to the metal-oxygen pair in metal oxides [50]. Of 86 particular interest is whether the ignition temperature $\left(T_{\mathrm{ig}}\right)$ is a predictable function of the 87 oxygen release temperature $\left(\mathrm{T}_{\mathrm{O} 2}\right)$, the melting temperature of aluminum $\left(\mathrm{T}_{\mathrm{Al}-\mathrm{melt}}\right)$, and the 88 melting temperature of oxidizer $\left(\mathrm{T}_{\text {oxidizer-melt }}\right)$.

89 In this paper, we systematically investigated the ignition of thermites that involve Al 90 and a variety of potassium oxysalts, in relation to the physiochemical changes of these 91 components during heating. These studies involved using constant-volume combustion 92 cell tests, thermal decomposition tests for oxysalts under both slow heating $(10 \mathrm{~K} / \mathrm{min})$ 93 and ultrafast heating $\left(\sim 10^{5} \mathrm{~K} / \mathrm{s}\right)$ conditions, and ignition tests for both microscale and 94 nanoscale thermites in air, in Ar and in vacuum. Nano-carbon-fueled thermites containing 95 similar oxysalts were also used as controls to tweeze out the role of liberated oxygen. 96

\section{2. Material and methods}

98 2.1. Materials

99 Nano-sized aluminum was obtained from Argonide Corporation, and nano-sized 100 carbon black was obtained from Cobot Corporation. Both materials have an average size 101 of $\sim 50 \mathrm{~nm}$. Micro-sized potassium persulfate $\left(\mathrm{K}_{2} \mathrm{~S}_{2} \mathrm{O}_{8}\right)$ powders were purchased from 102 Fluka. All of the other micro-sized oxysalt powders, namely potassium sulfate $\left(\mathrm{K}_{2} \mathrm{SO}_{4}\right)$, 103 potassium nitrate $\left(\mathrm{KNO}_{3}\right)$ potassium chlorate $\left(\mathrm{KClO}_{3}\right)$, potassium perchlorate $\left(\mathrm{KClO}_{4}\right)$, 104 potassium bromate $\left(\mathrm{KBrO}_{3}\right)$, potassium iodate $\left(\mathrm{KIO}_{3}\right)$, potassium periodate $\left(\mathrm{KIO}_{4}\right)$, and 105 potassium phosphate $\left(\mathrm{K}_{3} \mathrm{PO}_{4}\right)$ were purchased from Sigma-Aldrich. Scanning electron 
microscopy (SEM, Hitachi, SU-70 FEG-SEM) analysis shows that these as-received potassium oxysalts powders have a wide range of sizes from $1 \mu \mathrm{m}$ to $100 \mu \mathrm{m}$.

The corresponding nine nano-sized potassium oxysalts were prepared by an aerosol spray drying process, as is shown in Scheme 1. In short, $0.02 \mathrm{~mol} / \mathrm{L}$ water solution of oxysalt was prepared in the atomizer and sprayed into $1 \mu \mathrm{m}$ droplets by a pressured air 111 flow. Droplets flowed through a diffusion dryer to remove most of the water, followed by 112 complete dehydration by a tube furnace at $150{ }^{\circ} \mathrm{C}$ for $\mathrm{K}_{2} \mathrm{~S}_{2} \mathrm{O}_{8}$ and at $180{ }^{\circ} \mathrm{C}$ for the other 113 oxysalts. The dehydrated nanoparticles were finally collected on a Millipore membrane 114 filter with a pore size of $0.4 \mu \mathrm{m}$. The average size of nine nano-oxysalts is $\sim 0.5 \mu \mathrm{m}$. 115 Particle sizes were measured by SEM and statistically analysed from a random selection 116 of 60 particles in SEM images.

117 To prepare the thermite composite, nano-fuels ( $\mathrm{Al}$ or $\mathrm{C}$ ) were mixed with oxysalts 118 (microscale or nanoscale) in a stoichiometric ratio. Accounting for the alumina shell $119(30 \%)$ on the nano-Al, the actual weight of nano-Al added was 1.4 times higher. The 120 mixture was then sonicated in hexane for $30 \mathrm{~min}$ and then the solvent was evaporated at 121 room temperature. 1

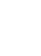

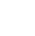

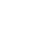
.

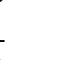
. 4 


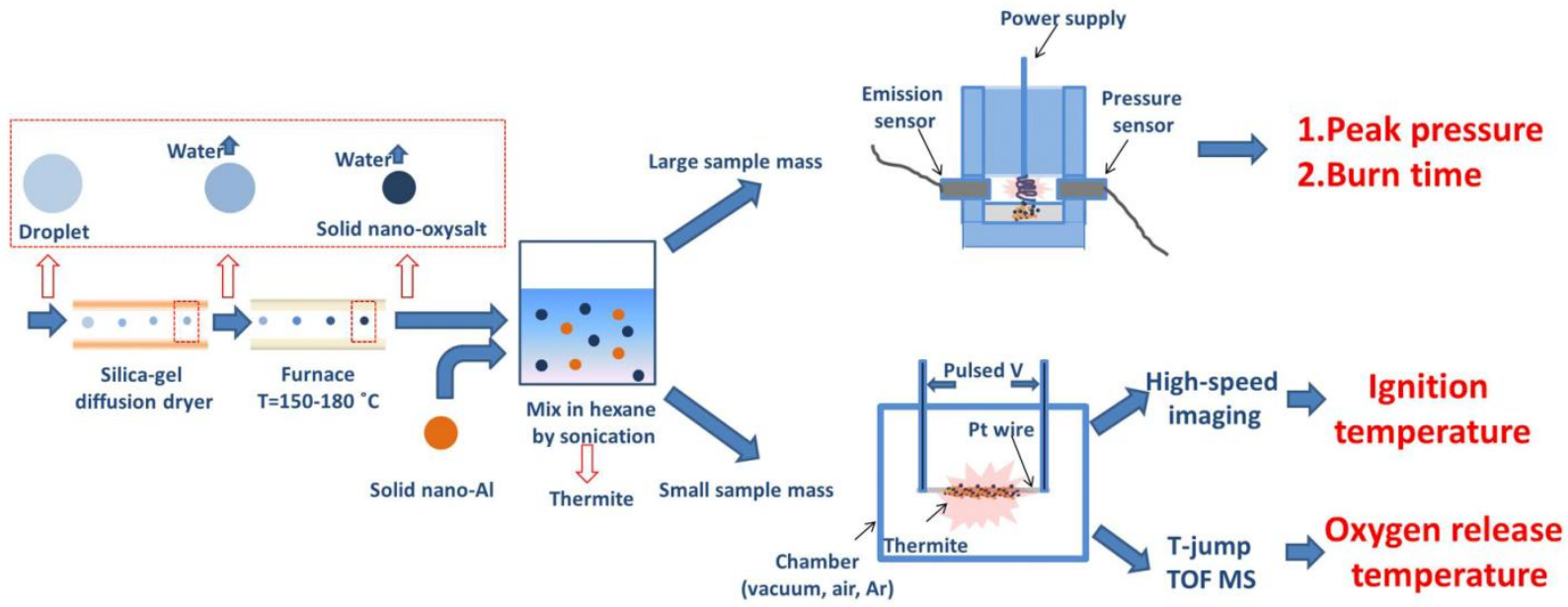

\subsection{Constant-volume combustion characterization}

Scheme 1. The experimental flow chart including spray drying process for sample preparation, $a$ pressure cell for detecting pressure and optical emission from thermite reaction, and a pulsed wire heating set-up coupled with T-jump TOF-MS and high-speed camera for detecting characteristic temperatures.

The analysis of nano-Al/micro-oxysalt thermite reactions was conducted in a constantvolume combustion cell (Scheme 1). Prior to tests, all the thermite samples were dried in vacuum for hours in order to mitigate the adverse influence of hygroscopicity. $25 \mathrm{mg}$ of thermite sample was loaded inside the combustion cell that has an internal spacing of $\sim 13$ $\mathrm{cm}^{3}$. After igniting the sample with a heated nichrome coil, the temporal pressure and optical emission from the thermite reaction were electronically recorded.

\subsection{TG-DSC analysis of the decomposition of oxysalts}

Thermogravimetry and differential scanning calorimetry (TG-DSC) tests of microscale oxysalts were conducted simultaneously in a SDT Q600 from TA Instruments, USA. 
Around $2 \mathrm{mg}$ of as-received oxysalt powders was loaded into the sample crucible inside

\subsection{T-jump TOF-MS analysis of the decomposition of oxysalts}

The decomposition of oxysalts (microscale or nanoscale) at ultrafast heating rates of $4 \times 10^{5} \mathrm{~K} / \mathrm{s}$ was investigated via temperature-jump time-of-flight mass spectrometry (Tjump TOF-MS, in-house assembled). A concentrated oxysalt powder suspension in hexane was deposited onto a $76 \mu \mathrm{m}$ Pt wire uniformly, to a thickness $<10 \mu \mathrm{m}$ so that the temperature of the deposit is approximated by the wire temperature. The loaded Pt wire was then inserted into the MS chamber and rapidly joule-heated to $\sim 1400 \mathrm{~K}$ by a $3 \mathrm{~ms}$ pulse. The temporal temperature of the wire was measured from the detected current and voltage according to the Callender-Van Dusen equation [51]. TOF-MS spectra was collected every $0.1 \mathrm{~ms}$. A detailed experimental description can be found in ref [52]. In the analysis of the MS results, the onset temperature of a specific species is defined based 162 on $5 \%$ of the maximum intensity of its MS peak. 


\subsection{Ignition tests of thermite reactions}

A Vision Research Phantom v12.0 high speed camera (14.9 $\mu$ s per frame) was employed to determine the onset of ignition on the wire. By mapping the temporal optical emission from the high-speed imaging, and the temporal wire temperature, the ignition temperatures of thermites were identified as the points where light intensities begin to rise. These experiments were carried out in vacuum, air or Ar.

\section{Results and discussion}

171 3.1. Reactivities of oxysalts in nano-aluminum-fueled thermites

172 We begin with the combustion performance of the nine Al-oxysalt thermites, in the 173 combustion cell test. Fig. 1 shows the maximum pressures, pressurization rates, and burn 174 times (the full-width half-maximum of the optical emission curve) for the thermite 175 reactions between nano-Al and micro-oxysalts. Also apparent in Fig. 1 is the very wide 176 range in performance, with the maximum peak pressures for $\mathrm{Al}-\mathrm{K}_{2} \mathrm{~S}_{2} \mathrm{O}_{8}, \mathrm{Al}-\mathrm{KClO}_{3}, \mathrm{Al}-$ $177 \mathrm{KIO}_{4}$ and $\mathrm{Al}-\mathrm{KClO}_{4}$ being more than six times larger than those of $\mathrm{Al}-\mathrm{K}_{2} \mathrm{SO}_{4}$ and $\mathrm{Al}-$ $178 \mathrm{~K}_{3} \mathrm{PO}_{4}$ (Fig. 1A), indicating that the former four thermites generated more gas during 179 reaction. A similar result in the pressurization rate was shown for these thermite reactions, 180 with the rates in thermites that release extensive gas $\left(\mathrm{Al}-\mathrm{K}_{2} \mathrm{~S}_{2} \mathrm{O}_{8}, \mathrm{Al}-\mathrm{KClO}_{3}, \mathrm{Al}-\mathrm{KIO}_{4}\right.$ and $\left.181 \mathrm{Al}-\mathrm{KClO}_{4}\right)$ more than one order of magnitude larger than the rates in less gas generating 182 thermites $\left(\mathrm{Al}-\mathrm{K}_{2} \mathrm{SO}_{4}\right.$ and $\left.\mathrm{Al}-\mathrm{K}_{3} \mathrm{PO}_{4}\right)$ (Fig. 1B). Not surprisingly, we also observed a 183 general relationship of higher peak pressure or pressurization rate corresponding to a 184 shorter burn time (Fig. 1C). The differences in these reaction characteristics indicate that 
A

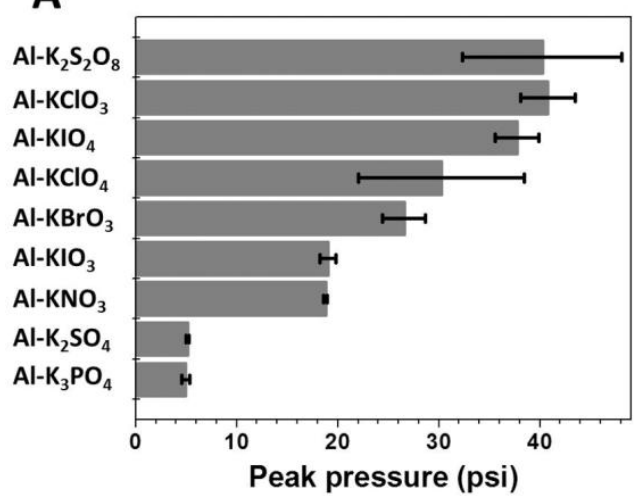

C

\section{B}

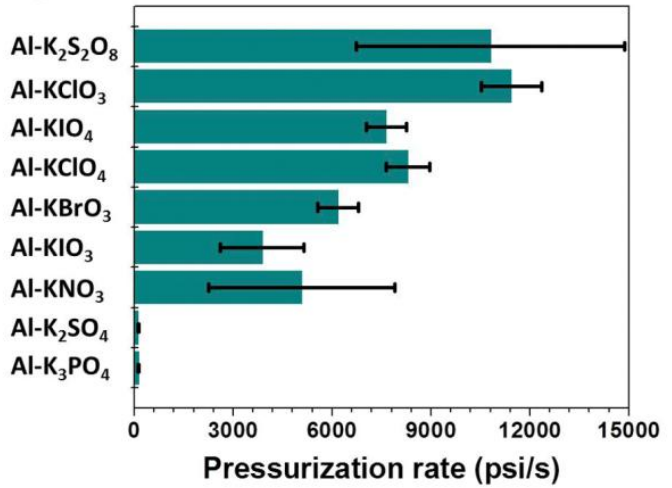

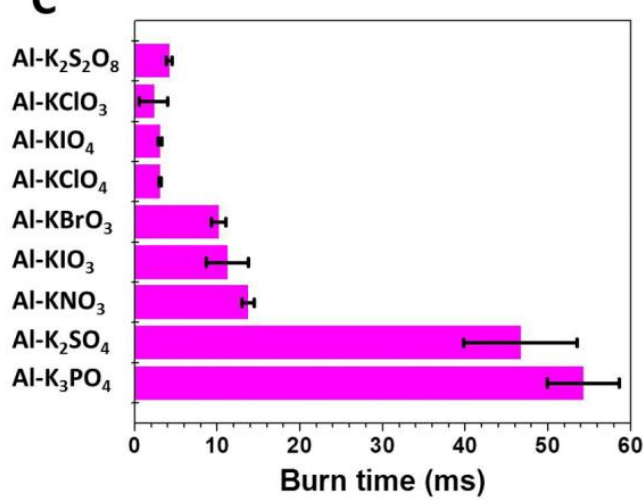

Fig. 1. Maximum pressure (A), pressurization rate (B), and burn time (C) for thermite reactions between nano-Al and micro-oxysalts. $25 \mathrm{mg}$ thermite sample was employed in each constant volume combustion cell test. Errors bars represent at least two experiments in parallel. 197 major gas species, adiabatic flame temperature, and reaction heat were calculated using

The combustion performance of some of these Al-oxysalt thermites was also assessed by thermodynamic equilibrium calculation as summarized in Table 1. The amount of gas generation, 


\section{Table 1}

Summary of the amount of gas generation, major gas species, adiabatic temperature and reaction heat from the Al-oxysalt thermite reactions. Thermodynamic data were calculated based on a constant enthalpy and pressure equilibrium using CHEETAH. The fuel and oxidizer were mixed in a stoichiometric ratio.

\begin{tabular}{ccccc}
\hline Formulations & cc gas $/ \mathrm{g}^{\mathrm{a}}$ & Major gas products (mol\%) & Adiabatic temperature $(\mathrm{K})$ & $\begin{array}{c}\text { Standard reaction } \\
\text { heat }(\mathrm{kJ} / \mathrm{g})^{\mathrm{b}}\end{array}$ \\
\hline $\mathrm{Al}+\mathrm{KNO}_{3}$ & $4.0 \times 10^{3}$ & $\mathrm{~K}(49 \%), \mathrm{N}_{2}(24 \%), \mathrm{Al}_{2} \mathrm{O}_{3}(25 \%)^{\mathrm{c}}$ & 3732 & -7.6 \\
$\mathrm{Al}+\mathrm{KClO}_{3}$ & $4.1 \times 10^{3}$ & $\mathrm{KCl}(55 \%)^{\mathrm{d}}, \mathrm{Al}_{2} \mathrm{O}_{3}(35 \%)^{\mathrm{c}}$ & 3791 & -9.8 \\
$\mathrm{Al}+\mathrm{KClO}_{4}$ & $4.2 \times 10^{3}$ & $\mathrm{KCl}(46 \%)^{\mathrm{d}}, \mathrm{Al}_{2} \mathrm{O}_{3}(44 \%)^{\mathrm{c}}$ & 3842 & -10.6 \\
$\mathrm{Al}+\mathrm{KBrO}_{3}$ & $3.4 \times 10^{3}$ & $\mathrm{KBr}(64 \%)^{\mathrm{d}}, \mathrm{Al}_{2} \mathrm{O}_{3}(34 \%)^{\mathrm{c}}$ & 3789 & -7.7 \\
$\mathrm{Al}+\mathrm{KIO}_{3}$ & $2.5 \times 10^{3}$ & $\mathrm{KI}(79 \%)^{\mathrm{d}}, \mathrm{Al}_{2} \mathrm{O}_{3}(20 \%)^{\mathrm{c}}$ & 3686 & -5.7 \\
$\mathrm{Al}+\mathrm{KIO}_{4}$ & $2.9 \times 10^{3}$ & $\mathrm{KI}(64 \%)^{\mathrm{d}}, \mathrm{Al}_{2} \mathrm{O}_{3}(35 \%)^{\mathrm{c}}$ & 3796 & -6.9 \\
$\mathrm{Al}+\mathrm{K}_{2} \mathrm{SO}_{4}$ & $4.7 \times 10^{2}$ & $\mathrm{~K}(66 \%), \mathrm{SO}_{2}(27 \%)$ & 2040 & -3.9 \\
$\mathrm{Al}+\mathrm{K}_{2} \mathrm{~S}_{2} \mathrm{O}_{8}{ }^{\mathrm{e}}$ & - & - & - & -5.8 \\
$\mathrm{Al}+\mathrm{K}_{3} \mathrm{PO}_{4}{ }^{\mathrm{e}}$ & - & - & - & -0.9 \\
\hline${ }^{\mathrm{e}} \mathrm{cc}=$ cubic centimeters & & & & \\
\hline
\end{tabular}


${ }^{b}$ The standard reaction heat (kilojoules per gram of thermite) was calculated for formulations with fuel/oxide in a stoichiometric ratio in the 1atm, $298 \mathrm{~K}$ condition. The reaction equations were shown in eq. S1-S9, and also in Fig. S1. The standard heat of formation for each reaction/product (Table S1) was used to calculate the reaction heat.

\subsection{Thermal decomposition of oxysalts at slow heating rates $(10 \mathrm{~K} / \mathrm{min})$}

Since the gas generation appears to be correlated to the reactivity of oxysalt-containing thermites (Fig. 1), the thermal decomposition of neat microscale oxysalt powders was examined to identify the species and the temperature of gas evolution. TG-DSC results (Fig. S1) demonstrate that these oxysalts show different onset temperatures of physicochemical changes. The primary thermal results for onset temperature, gas release, and product identification are summarized in Table 2. In general, all of the nine oxysalts generate $\mathrm{O}_{2}$ at different stages, with $\mathrm{K}_{2} \mathrm{~S}_{2} \mathrm{O}_{8}$ showing the lowest $\mathrm{O}_{2}$ generation temperature, while $\mathrm{K}_{2} \mathrm{SO}_{4}$ and $\mathrm{K}_{3} \mathrm{PO}_{4}$ release $\mathrm{O}_{2}$ at temperatures several hundreds of Kelvin higher than the other oxysalts. In relation to the corresponding thermite reactions (Fig. 1A), we find that the oxysalt having a low $\mathrm{O}_{2}$ release temperature usually corresponds to a thermite event with a high pressure and faster overall reaction (also see Fig. S2 for the relationships between $\mathrm{O}_{2}$ release temperature and peak pressure (Fig. S2A) 235 or pressurization rate (Fig. S2B)). This indicates that the oxygen release temperature is a 236 good metric for evaluating oxysalt-containing thermites.

237 It is interesting to note that many oxysalts in Table 2 have a melting temperature lower 238 than the $\mathrm{O}_{2}$ release temperature. Considering the much higher oxygen mobility in a melt, 
a melting event commencing prior to thermal decomposition $\left(\mathrm{O}_{2}\right.$ release $)$ may also have a potential impact on initiating the thermite reaction.

Table 2

Summary of the thermal decomposition events of oxidizers during heating $(10 \mathrm{~K} / \mathrm{min})$. The onset temperature and relevant products in each event are listed. The parentheses show the melting phase change of oxidizers.

\begin{tabular}{|c|c|c|c|c|c|c|}
\hline Oxidizers & Temperature $(\mathrm{K})$ & Events & Products & Temperature (K) & Events & Products \\
\hline $\mathrm{K}_{2} \mathrm{~S}_{2} \mathrm{O}_{8}$ & 556 & Decomposition & $\mathrm{K}_{2} \mathrm{~S}_{2} \mathrm{O}_{7}, \mathrm{O}_{2}$ & 725 & Decomposition & $\mathrm{K}_{2} \mathrm{SO}_{4}, \mathrm{O}_{2}, \mathrm{SO}_{2}{ }^{\mathrm{a}}$ \\
\hline $\mathrm{K}_{2} \mathrm{SO}_{4}$ & 1357 & Melting & $\mathrm{K}_{2} \mathrm{SO}_{4}(\mathrm{l})$ & 1394 & Decomposition & $\mathrm{K}, \mathrm{O}_{2}, \mathrm{SO}_{2}{ }^{\mathrm{b}}$ \\
\hline $\mathrm{KIO}_{4}$ & 613 & Decomposition & $\mathrm{KIO}_{3}, \mathrm{O}_{2}$ & 797 & Decomposition & $\mathrm{KI}, \mathrm{O}_{2}{ }^{\mathrm{c}}$ \\
\hline $\mathrm{KIO}_{3}$ & 809 & Decomposition & $\mathrm{KI}, \mathrm{O}_{2}{ }^{\mathrm{c}}$ & - & - & - \\
\hline $\mathrm{KClO}_{4}$ & 877 & Melting & $\mathrm{KClO}_{4}(\mathrm{l})$ & 895 & Decomposition & $\mathrm{KCl}, \mathrm{O}_{2}{ }^{\mathrm{c}}$ \\
\hline $\mathrm{KClO}_{3}$ & 695 & Melting & $\mathrm{KClO}_{3}(\mathrm{l})$ & 745 & Decomposition & $\mathrm{KCl}, \mathrm{O}_{2}{ }^{\mathrm{c}}$ \\
\hline $\mathrm{KBrO}_{3}$ & 680 & Melting & $\mathrm{KBrO}_{3}(\mathrm{l})$ & 699 & Decomposition & $\mathrm{KBr}, \mathrm{O}_{2}{ }^{\mathrm{c}}$ \\
\hline $\mathrm{KNO}_{3}$ & 601 & Melting & $\mathrm{KNO}_{3}(\mathrm{l})$ & 913 & Decomposition & $\mathrm{K}, \mathrm{O}_{2}, \mathrm{NO}_{2}{ }^{\mathrm{d}}$ \\
\hline $\mathrm{K}_{3} \mathrm{PO}_{4}$ & 1347 & Melting & $\mathrm{K}_{3} \mathrm{PO}_{4}(\mathrm{l})$ & 1539 & Decomposition & $\mathrm{K}_{2} \mathrm{O}, \mathrm{P}, \mathrm{O}_{2}{ }^{\mathrm{e}}$ \\
\hline
\end{tabular}

${ }^{a}$ The final products from the decomposition of $\mathrm{K}_{2} \mathrm{~S}_{2} \mathrm{O}_{8}$ are referred to [50].

${ }^{b}$ The final products from the decomposition of $\mathrm{K}_{2} \mathrm{SO}_{4}$ are referred to [53].

${ }^{c}$ The final products from the decomposition of $\mathrm{KIO}_{3}, \mathrm{KIO}_{4}, \mathrm{KClO}_{3}, \mathrm{KClO}_{4}$ and $\mathrm{KBrO}_{3}$ are measured from our TG-DSC results (Fig. S1).

${ }^{d}$ The final products from the decomposition of $\mathrm{KNO}_{3}$ are referred to [54].

${ }^{e}$ The final products from the decomposition of $\mathrm{K}_{3} \mathrm{PO}_{4}$ are referred to [55].

\subsection{Thermal decomposition of oxysalts at ultrafast heating rates $\left(4 \times 10^{5} \mathrm{~K} / \mathrm{s}\right)$}

256 combustion event, T-jump TOF-MS at a heating rate of $4 \times 10^{5} \mathrm{~K} / \mathrm{s}$ was employed, and 257 the onset temperatures for corresponding generated gases were determined. As an example, the overall temporal MS intensity of molecular oxygen released from $\mathrm{K}_{2} \mathrm{~S}_{2} \mathrm{O}_{8}$ is 


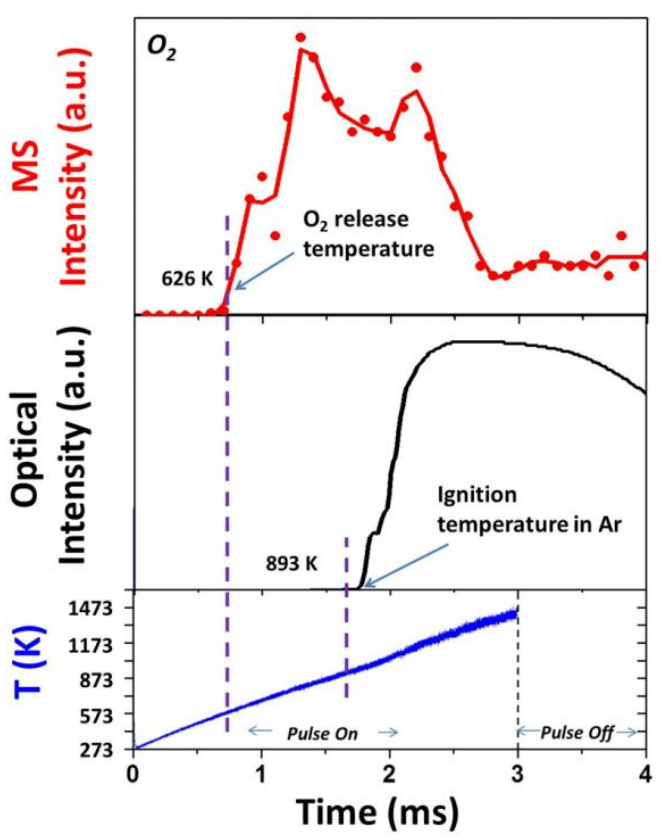

Fig. 2. Temporal oxygen release from $\mathrm{K}_{2} \mathrm{~S}_{2} \mathrm{O}_{8}$ decomposition, and temporal optical emission from Al$\mathrm{K}_{2} \mathrm{~S}_{2} \mathrm{O}_{8}$ reaction under ultrafast heating $\left(4 \times 10^{5} \mathrm{~K} / \mathrm{s}\right)$. The bottom panel shows the temporal temperature trace from the Pt wire. The middle panel shows the temporal trace of optical intensity from the thermite reaction in $\mathrm{Ar}$, with the designated ignition temperature $(893 \mathrm{~K})$. The top panel shows the temporal MS intensity of oxygen release from the decomposition of $\mathrm{K}_{2} \mathrm{~S}_{2} \mathrm{O}_{8}$, with the onset temperature at $626 \mathrm{~K}$.

\subsection{T-jump ignition temperature}



profiles. For example as shown in Fig. 2, the ignition temperature of nano-Al/micro$\mathrm{K}_{2} \mathrm{~S}_{2} \mathrm{O}_{8}$ in $\mathrm{Ar}$ was measured to be $893 \mathrm{~K}$ as the onset of optical increase. Given that this ignition temperature is $\sim 270 \mathrm{~K}$ higher than the $\mathrm{O}_{2}$ release temperature (Fig. 2), we previously speculated that the $\mathrm{O}_{2}$ release is one of the prerequisites for ignition, while it does not determine the initiation of $\mathrm{Al}-\mathrm{K}_{2} \mathrm{~S}_{2} \mathrm{O}_{8}$ reaction [50]. We raise an important question in this study as to whether $\mathrm{O}_{2}$ release prior to ignition is necessary for the initiation of the other Al-oxysalt reactions.

To address this issue, we compared the $\mathrm{O}_{2}$ release temperatures and ignition temperatures of all the nine nano-Al/micro-oxysalt thermites in Fig. 3. Fig. 3A shows that although $\mathrm{Al}-\mathrm{KNO}_{3}, \mathrm{Al}-\mathrm{KClO}_{4}, \mathrm{Al}-\mathrm{KIO}_{3}, \mathrm{Al}-\mathrm{KClO}_{3}, \mathrm{Al}-\mathrm{KBrO}_{3}, \mathrm{Al}-\mathrm{KIO}_{4}$, and Al$\mathrm{K}_{2} \mathrm{~S}_{2} \mathrm{O}_{8}$ have different $\mathrm{O}_{2}$ release temperatures, they all ignited around the same temperature in Ar, and nominally $\sim 50 \mathrm{~K}$ below the melting point of Al. Furthermore, ignition appears to be insensitive to available gas phase oxygen since the ignition temperature in Ar and air appear to be similar. The dotted vertical line in the plot (Fig. 3A) corresponds to the melting point of aluminum, and it appears that most of the ignition temperatures are aligned vertically and parallel to the dotted line, and thus do not correlate with the $\mathrm{O}_{2}$ release temperature. These results imply that the ignition of the Aloxysalt thermites is dominated by the accelerated outward diffusion of $\mathrm{Al}$ when approaching its melting point. The generated $\mathrm{O}_{2}$ concentration locally from the decomposition of oxysalts is much higher than that in air (see supplemental information for the detailed comparison of the $\mathrm{O}_{2}$ concentrations in film and in air), so that the effect of $\mathrm{O}_{2}$ in air is minimal to the ignition temperature of reactive Al-oxysalt thermites (Fig. 
3A). However, when ignited in vacuum, these thermites show strikingly increased and distinct ignition temperatures (Fig. 3B). Gaseous oxygen generated from the oxysalt will presumably have little time to interact with $\mathrm{Al}$ in vacuum (see supplemental information for the detailed estimation of the $\mathrm{O}_{2}$ residence time in thermite film both in air and in vacuum), therefore the delayed and thus higher temperature ignition in vacuum should be attributed to condensed phase transfer of oxygen.

The constant ignition temperature for these Al-oxysalt thermites at $\sim 880 \mathrm{~K}$ corresponds to a critical phase change in the $\mathrm{Al}$ particle shell from amorphous $(<880 \mathrm{~K})$ to $\gamma$-alumina [22]. Trunov et al. reported that the density of $\gamma$-alumina is larger than amorphous alumina, thus the newly formed $\gamma$-alumina at $\sim 880 \mathrm{~K}$ was not able to form a continuous dense layer outside the Al particle [22]. This partially covered shell facilitates the accelerated diffusion of $\mathrm{Al}$, resulting in the increased oxidation rate of $\mathrm{Al}$, which from the perspective of ignition, refers to the consistent ignition temperature for the reactive Aloxysalt thermites at $\sim 880 \mathrm{~K}$.

The reaction behaviour of $\mathrm{Al}-\mathrm{K}_{2} \mathrm{SO}_{4}$ and $\mathrm{Al}-\mathrm{K}_{3} \mathrm{PO}_{4}$ thermites is clearly very different from the other seven thermites. Fig. 3A shows that their ignition temperatures in Ar are 313 more than $100 \mathrm{~K}$ higher than the melting temperature of $\mathrm{Al}$. In this case, $\mathrm{Al}$ is completely 314 melted and most likely in intimate contact with the oxysalt. Considering that their $\mathrm{O}_{2}$ 315 release temperatures are even higher than their ignition temperatures, the ignition of Al$316 \mathrm{~K}_{2} \mathrm{SO}_{4}$ an $\mathrm{Al}-\mathrm{K}_{3} \mathrm{PO}_{4}$ thermites presumably follows a condense phase route similar to the 317 aforementioned case for the other thermites in vacuum (Fig. 3B). This postulated 318 condense phase reaction mechanism for $\mathrm{Al}-\mathrm{K}_{2} \mathrm{SO}_{4}$ and $\mathrm{Al}-\mathrm{K}_{3} \mathrm{PO}_{4}$ thermites is further 319 confirmed by their unchanged ignition temperatures in vacuum (Fig. 3B). However, when 
ignited in air, both $\mathrm{Al}-\mathrm{K}_{2} \mathrm{SO}_{4}$ and $\mathrm{Al}-\mathrm{K}_{3} \mathrm{PO}_{4}$ thermites show decreased ignition
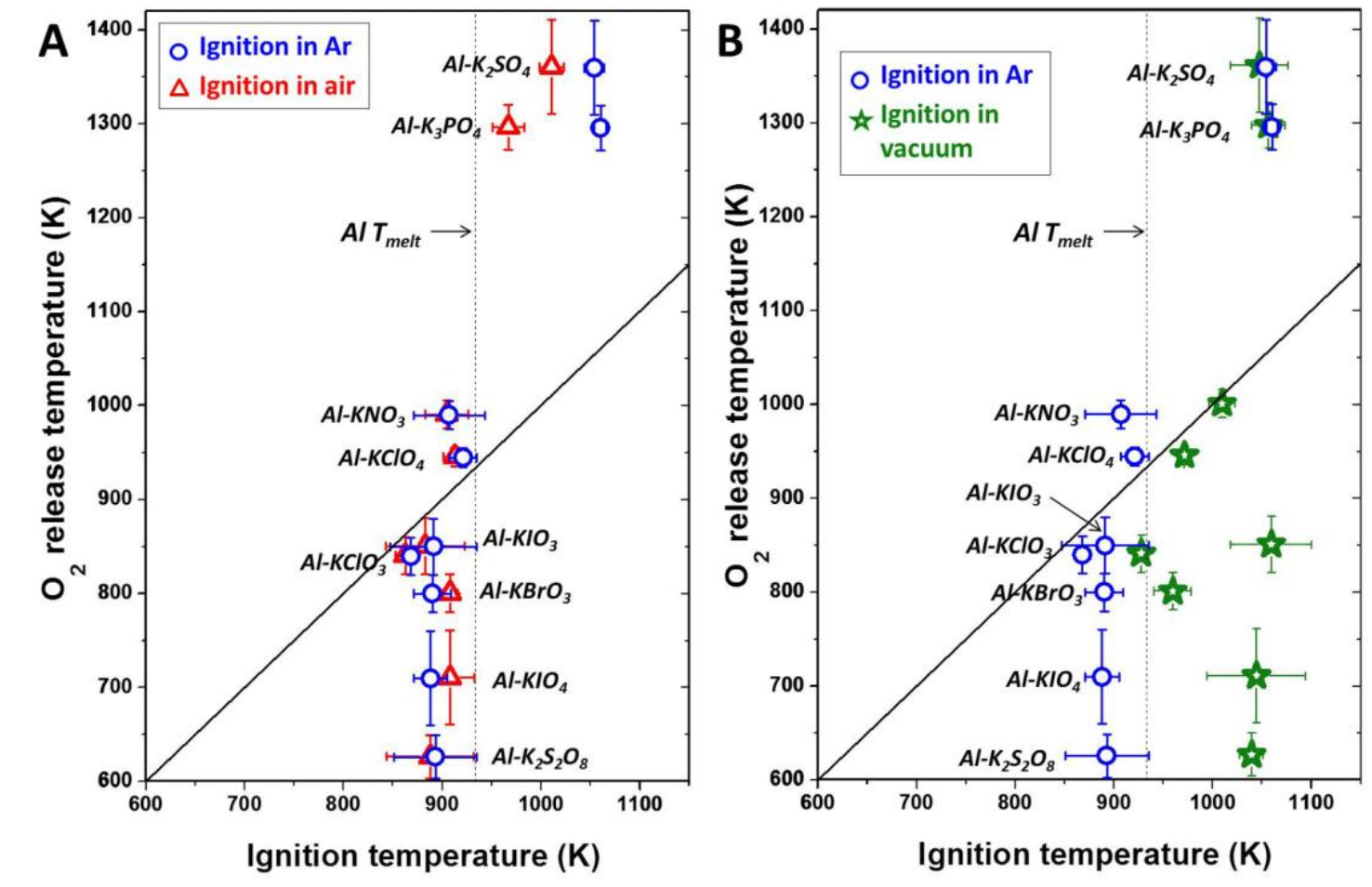
temperatures approaching the melting temperature of $\mathrm{Al}$ (Fig. 3A). This is consistent with these oxysalts acting almost as dead weight and the aluminum penetrating the alumina shell above its melting point to ignite with gaseous oxygen.

Fig. 3. (A) Relationship between the oxygen release temperature in neat microscale oxysalt, and the ignition temperature of corresponding nano-Al-fueled thermite in Ar or in air. (B) Relationship between the oxygen release temperature in neat microscale oxysalt, and the ignition temperature of corresponding nano-Al-fueled thermite in Ar or in vacuum. Each temperature test was repeated at least twice. The diagonal solid line stands for a perfect correlation. The vertical dashed line indicates the melting temperature of Al (933 K).

We also conducted similar experiments by decreasing the dimension of oxysalts to nanometer scales so that the contact area between the fuel and oxidizer can be significantly increased. The motivation of this control experiment is to further evaluate 
our proposed reaction mechanism that includes reactive gaseous oxygen. Fig. S3 and Table S3 show a consistent correlation between ignition temperatures of the nanoAl/nano-oxysalt thermites in Ar, air and vacuum, similar to Fig. 3 for nano-Al/microoxysalt thermites. To understand the effect of the powder size of oxysalts, a typical comparison of the $\mathrm{O}_{2}$ release temperature and the ignition temperature between nano$\mathrm{Al} /$ nano-oxysalt and nano-Al/micro-oxysalt thermites in $\mathrm{Ar}$ was conducted in Fig. 4. Compared with the nano-Al/micro-oxysalt thermites, the nano- $\mathrm{Al} /$ micro-oxysalt thermites 343 of $\mathrm{Al}-\mathrm{K}_{2} \mathrm{SO}_{4}$ and $\mathrm{Al}-\mathrm{K}_{3} \mathrm{PO}_{4}$ show more than $50 \mathrm{~K}$ reduction both in $\mathrm{O}_{2}$ release and 344 ignition temperatures. Since both thermites follow a condense phase reaction mechanism, 345 it is reasonable to see the decrease in these characteristic temperatures due to the increase 346 of contact area between $\mathrm{Al}$ and oxysalt. In contrast, the ignition temperatures for the other 347 seven thermites are independent of particle size, indicating that it is the reaction of $\mathrm{Al}$ and 348 gaseous $\mathrm{O}_{2}$ that contributes to the combustion initiation (Fig. 4). 


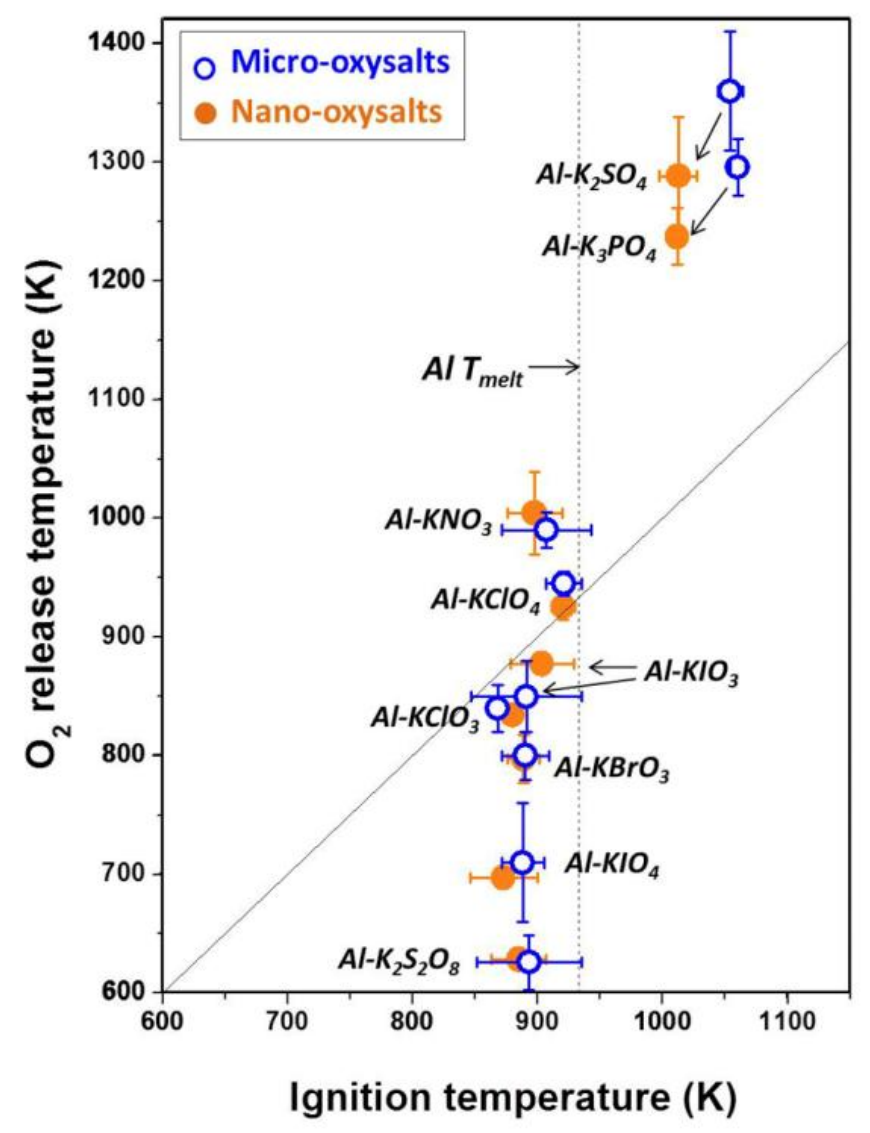

Our proposed dual-phase reaction mechanism for reactive Al-oxysalts thermites, if

Fig. 4. Effect of particle size: relationship between the oxygen release temperature in neat nanoscale and microscale oxysalts, and the ignition temperature of corresponding nano-Al-fueled thermite in Ar. The arrows designate the temperature shifts of both ignition temperatures and oxygen release temperatures for $\mathrm{Al}-\mathrm{K}_{2} \mathrm{SO}_{4}$ and $\mathrm{Al}-\mathrm{K}_{3} \mathrm{PO}_{4}$ thermites when the dimension of oxysalt drops from micrometer scale to nanometer scale.

361 aluminum core (Fig. 3). The ignition temperatures of the seven reactive Al-oxysalt 
thermites were close to the aluminum melting point in both Ar and air (Fig. 3A and Fig. S3A) even though the corresponding oxysalts have different $\mathrm{O}_{2}$ release temperatures. This indicates that the ignition was controlled by the accelerated outward diffusion of aluminum. However, this result provides no indication as to the nature of the reactive oxygen species that reacts with Al. The fact that in vacuum, where we expect little gas phase oxygen to play a role, the ignition temperature increases suggests that the initiating mechanism transitions from an oxygen gas reaction to a condensed phase oxygen exchange process.

To further explore this point we employ carbon as a fuel, because unlike Al, it has a very high melting temperature, thus no fuel mobility (> $3800 \mathrm{~K}$ ), and since there is no oxide shell, the fuel is directly accessible to the oxidizer. Fig. 5 and Table S4 shows that in contrast to $\mathrm{Al}$, where ignition was confined to near the melting point of $\mathrm{Al}$ regardless of oxidizer species, the reactive nano-carbon/micro-oxysalt thermites $\left(\mathrm{Al}-\mathrm{KNO}_{3}, \mathrm{Al}-\mathrm{KClO}_{4}\right.$, $\mathrm{Al}-\mathrm{KIO}_{3}, \mathrm{Al}-\mathrm{KClO}_{3}, \mathrm{Al}-\mathrm{KBrO}_{3}$, and $\mathrm{Al}-\mathrm{KIO}_{4}$ ) have a near perfect linear correlation between ignition and $\mathrm{O}_{2}$ release temperatures both in $\mathrm{Ar}$ and in air. These reactive thermites are incombustible in vacuum, probably due to a lower reactivity of $\mathrm{C}$ than $\mathrm{Al}$. These results clearly indicate that the reactive oxygen that leads to ignition with the surface bound carbon is from the released molecular oxygen, thus confirming the Al$\mathrm{O}_{2}(\mathrm{~g})$ reaction mechanism for the reactive oxysalt-containing thermites.

Two exceptions are $\mathrm{C}-\mathrm{K}_{2} \mathrm{SO}_{4}$ and $\mathrm{C}-\mathrm{K}_{3} \mathrm{PO}_{4}$, which are not combustible in Ar, while have higher ignition temperatures than their $\mathrm{O}_{2}$ release temperatures in air. This result confirms our previous interpretation that the less reactive thermites undergo a condense phase reaction mechanism. 


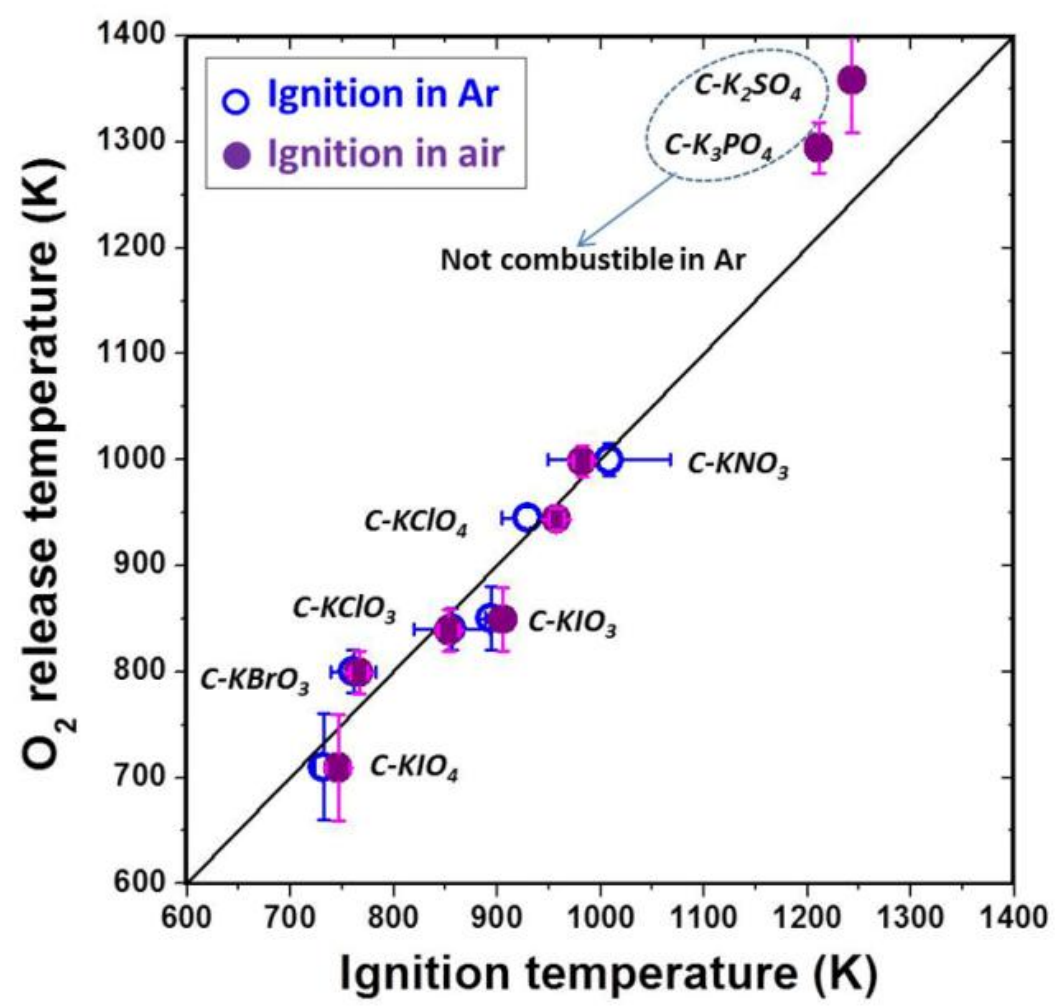

Fig. 5. Relationship between the oxygen release temperature in neat microscale oxysalt, and the ignition temperature of corresponding nano-carbon-fueled thermite in Ar or in air. Each temperature test was repeated at least twice. The diagonal solid line stands for a perfect correlation. $C-\mathrm{K}_{2} \mathrm{SO}_{4}$ and $C-\mathrm{K}_{3} \mathrm{PO}_{4}$ thermites were found to be not combustible in Ar, and thus the relevant ignition temperatures were vacant in the diagram.

\section{3.5. Reaction mechanisms}

393 Here we summarize the experimental results within a framework of some plausible 394 mechanisms as illustrated in Fig 6. In this study we consider mainly four characteristic 395 temperatures. The ignition temperature $\left(T_{i g}\right)$, the oxygen release temperature $\left(T_{O 2}\right)$, the phase change temperature for the alumina shell $\left(\mathrm{T}_{\gamma \text {-Al203 }}\right.$, which is close to the melting 397 temperature of aluminium, $\left.\mathrm{T}_{\mathrm{Al}-\mathrm{melt}}\right)$, and the melting temperature of oxysalt $\left(\mathrm{T}_{\text {oxidizer-melt }}\right)$. 
The nine Al-oxysalt thermites can be generally divided into two groups. The first group includes $\mathrm{Al}-\mathrm{K}_{2} \mathrm{~S}_{2} \mathrm{O}_{8}, \mathrm{Al}-\mathrm{KIO}_{4}, \mathrm{Al}-\mathrm{KIO}_{3}, \mathrm{Al}-\mathrm{KClO}_{3}$ and $\mathrm{Al}-\mathrm{KBrO}_{3}$ as they fall below the diagonal in Fig. 3A. These thermites have $\mathrm{T}_{\mathrm{O} 2}<\mathrm{T}_{\gamma \text {-Al2O3 }}=\mathrm{T}_{\mathrm{ig}}<\mathrm{T}_{\mathrm{Al}-\mathrm{melt}}$, and minimal or lower $\mathrm{T}_{\text {oxidizer-melt }}$. The ignition for these thermites is driven by the interaction of released $\mathrm{O}_{2}$ from the oxysalt and the accelerated outwardly diffusing $\mathrm{Al}$ atoms when the temperature of the polymorphic phase change in alumina $(\sim 880 \mathrm{~K}$, from amorphous to $\gamma$ $\mathrm{Al}_{2} \mathrm{O}_{3}$ ) is reached (which also approaches $\mathrm{T}_{\mathrm{Al}-\mathrm{melt}}$ at $\sim 930 \mathrm{~K}$ ) [22]. This phase change at $\sim 880 \mathrm{~K}$ features some degree of porosity in the alumina shell due to the increase of alumina density, leading to the enhancement of Al diffusion across the alumina shell, and therefore the initiation of thermite reaction. Two thermites including $\mathrm{Al}-\mathrm{KNO}_{3}$ and Al$\mathrm{KClO}_{4}$ have a transformed ignition type subordinate to the first group (Fig. S4), which ignite before oxygen is released. These are the thermites that are found above the diagonal in Fig. 3A. In this case, the oxysalt melts prior to ignition $\left(\mathrm{T}_{\text {oxidizer-melt }}<\mathrm{T}_{\gamma-\mathrm{Al} 2 \mathrm{O} 3}\right.$ $=\mathrm{T}_{\mathrm{ig}}<\mathrm{T}_{\mathrm{O} 2}$, , thus the thermite must initially be ignited by the interaction of bound oxygen 412 in the molten oxysalt and accelerated outwardly diffused $\mathrm{Al}$ at the temperature of 413 polymorphic phase change in the alumina shell $\left(\sim 880 \mathrm{~K}\right.$, close by $\left.\mathrm{T}_{\mathrm{Al}-\mathrm{melt}}\right)$. Once ignition 414 commences, self-heating will generate gaseous oxygen which then will be the 415 predominant reaction mechanism, as the in-vacuum experiments illustrate (Fig. 3B). The 416 second group of thermites includes $\mathrm{Al}-\mathrm{K}_{2} \mathrm{SO}_{4}$ and $\mathrm{Al}-\mathrm{K}_{3} \mathrm{PO}_{4}$ that are substantially above 417 the diagonal (Fig. 3A) and thus gas-phase generated oxygen cannot be important. The 418 ignition temperatures for these less reactive thermites are higher than $\mathrm{T}_{\mathrm{Al}-\mathrm{melt}}$, while lower 419 than $\mathrm{T}_{\mathrm{O} 2}$ (Fig. 3A), suggesting that ignition is determined by the accelerated outward flow of oxygen from the melt oxysalt $\left(\mathrm{T}_{\mathrm{Al}-\mathrm{melt}}<\mathrm{T}_{\text {oxidizer-melt }}=\mathrm{T}_{\mathrm{ig}}<\mathrm{T}_{\mathrm{O} 2}\right)$. These results 
2

3

421 demonstrate that ignition of Al-oxysalt thermites requires both the availability of $\mathrm{Al}$ and oxygen at the reaction interface, and is much related to the temperature of polymorphic phase change for alumina $\left(\mathrm{T}_{\gamma \text {-Al2O3 }}\right)$. The first group of thermites has a lower temperature

424 for oxygen availability (either $\mathrm{T}_{\mathrm{O} 2}$ or $\mathrm{T}_{\text {oxidizer-melt }}$ ) than $\mathrm{T}_{\gamma \text {-Al2O33 }}$, thus ignition for these
425 formulations is triggered by the accelerated diffusion of $\mathrm{Al}\left(\mathrm{T}_{\mathrm{ig}}=\mathrm{T}_{\gamma \text {-Al2O3). Conversely, }}\right.$,
426 the other group of thermites has a higher temperature for oxygen availability (mainly
$\left.427 \mathrm{~T}_{\text {oxidizer-melt }}\right)$ than $\mathrm{T}_{\gamma \text {-Al203 }}$, thus the limiting step in triggering is the accelerated diffusion of

424 for oxygen availability (either $\mathrm{T}_{\mathrm{O} 2}$ or $\mathrm{T}_{\text {oxidizer-melt }}$ ) than $\mathrm{T}_{\gamma \text {-Al2O33 }}$, thus ignition for these
425 formulations is triggered by the accelerated diffusion of $\mathrm{Al}\left(\mathrm{T}_{\mathrm{ig}}=\mathrm{T}_{\gamma \text {-Al2O3). Conversely, }}\right.$,
426 the other group of thermites has a higher temperature for oxygen availability (mainly
$\left.427 \mathrm{~T}_{\text {oxidizer-melt }}\right)$ than $\mathrm{T}_{\gamma \text {-Al203 }}$, thus the limiting step in triggering is the accelerated diffusion of

424 for oxygen availability (either $\mathrm{T}_{\mathrm{O} 2}$ or $\mathrm{T}_{\text {oxidizer-melt }}$ ) than $\mathrm{T}_{\gamma \text {-Al2O33 }}$, thus ignition for these
425 formulations is triggered by the accelerated diffusion of $\mathrm{Al}\left(\mathrm{T}_{\mathrm{ig}}=\mathrm{T}_{\gamma \text {-Al2O3). Conversely, }}\right.$,
426 the other group of thermites has a higher temperature for oxygen availability (mainly
$\left.427 \mathrm{~T}_{\text {oxidizer-melt }}\right)$ than $\mathrm{T}_{\gamma \text {-Al203 }}$, thus the limiting step in triggering is the accelerated diffusion of

424 for oxygen availability (either $\mathrm{T}_{\mathrm{O} 2}$ or $\mathrm{T}_{\text {oxidizer-melt }}$ ) than $\mathrm{T}_{\gamma \text {-Al2O33 }}$, thus ignition for these
425 formulations is triggered by the accelerated diffusion of $\mathrm{Al}\left(\mathrm{T}_{\mathrm{ig}}=\mathrm{T}_{\gamma \text {-Al2O3). Conversely, }}\right.$,
426 the other group of thermites has a higher temperature for oxygen availability (mainly
$\left.427 \mathrm{~T}_{\text {oxidizer-melt }}\right)$ than $\mathrm{T}_{\gamma \text {-Al203 }}$, thus the limiting step in triggering is the accelerated diffusion of 428 oxygen $\left(\mathrm{T}_{\mathrm{ig}}=\mathrm{T}_{\text {oxidizer-melt }}\right)$.

429 For the ignition of nano-C with oxidizers, since carbon is solid and has no oxide shell 430 at all the ignition temperatures, ignition is simply controlled by the availability of reactive 431 oxygen from the oxidizers (decomposition or melting) (Fig. 6B). Thus, most of the 432 ignition temperatures are linearly correlated to the relevant $\mathrm{O}_{2}$ release temperature or 433 melting temperature of oxidizers. 


\section{A). Al-oxysalt}

Group 1: Gas solid reaction $\left(\mathrm{T}_{\mathrm{O2}}<\mathrm{T}_{\mathrm{v}-\mathrm{Al} 2 \mathrm{O3}}=\mathrm{T}_{\mathrm{ig}}\right)$
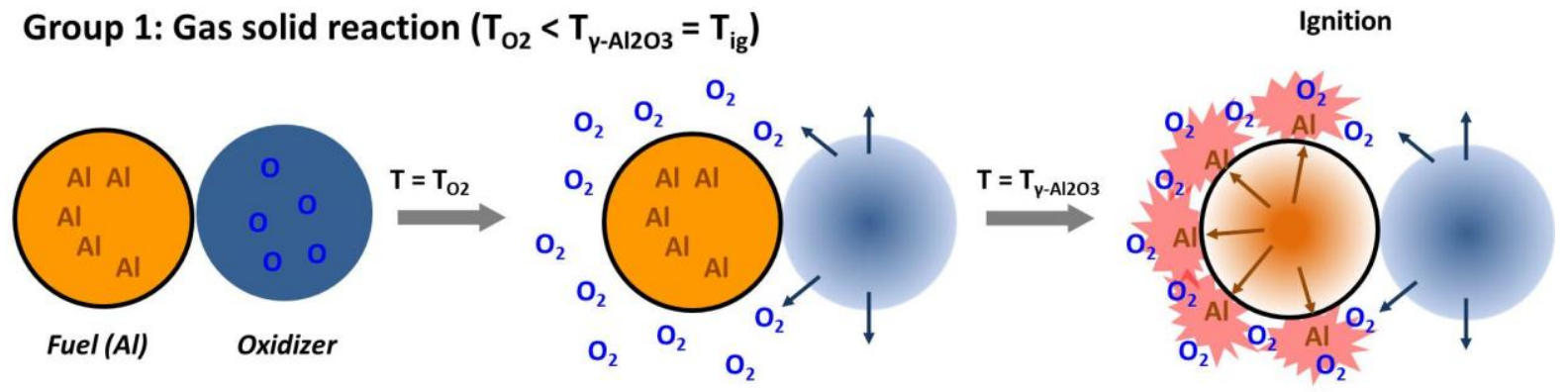

Group 2: Condensed phase reaction $\left(\mathrm{T}_{\mathrm{Al}-\mathrm{melt}}<\mathrm{T}_{\text {oxidizer-melt }}=\mathrm{T}_{\mathrm{ig}}\right)$
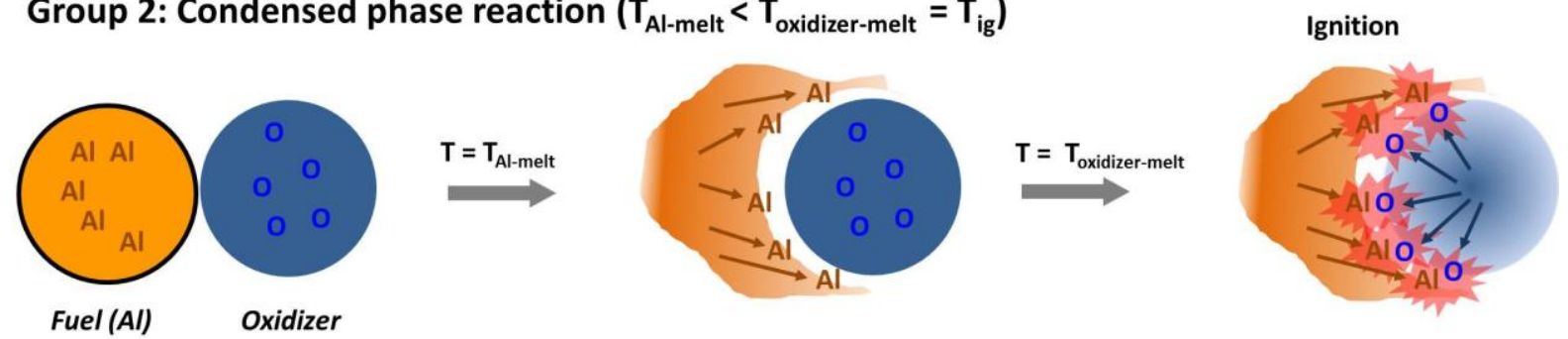

\section{B). C-oxysalt}
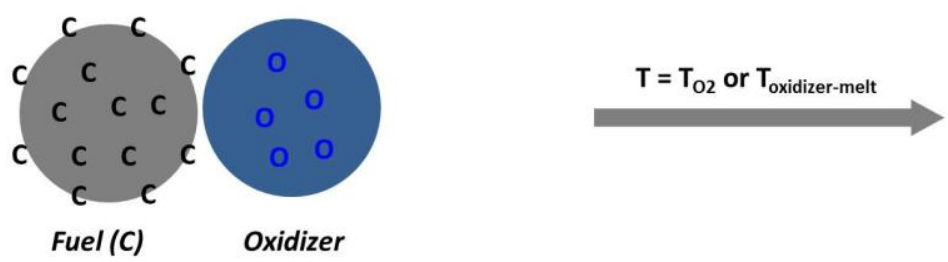

\section{Conclusions}

439 We implemented a study of the reaction mechanisms of oxysalt-containing thermites. Based 440 on their combustion behavior, nine oxysalt-containing thermites were divided into two groups, 441 with the reactive thermites (e.g., Al- $\left.\mathrm{K}_{2} \mathrm{~S}_{2} \mathrm{O}_{8}\right)$ showing $\sim 10 \times$ higher maximum pressure, and $442 \sim 10 \times$ shorter burn time than the less reactive thermites (e.g., Al- $\left.\mathrm{K}_{2} \mathrm{SO}_{4}\right)$. The difference in 443 ignition temperature $\left(\mathrm{T}_{\mathrm{ig}}\right)$ is attributed to the oxygen release temperature $\left(\mathrm{T}_{\mathrm{O} 2}\right)$, the temperature 
444 of polymorphic phase change for alumina $\left(\mathrm{T}_{\gamma \text {-Al2O3 }}\right)$, and the melting temperature of oxysalt ( $\left.\mathrm{T}_{\text {oxidizer-melt }}\right)$. The basic results are: (1) $\mathrm{T}_{\mathrm{ig}}$ of the reactive thermites in Ar and in air are similar to $\mathrm{T}_{\gamma \text {-Al2O3 }}$ (close to $\mathrm{T}_{\mathrm{Al}-\mathrm{melt}}$ ), while the corresponding $\mathrm{T}_{\mathrm{ig}}$ in vacuum are higher; (2) $\mathrm{T}_{\mathrm{ig}}$ of the less reactive thermites in $\mathrm{Ar}$ and in vacuum are consistent, and much higher than $\mathrm{T}_{\mathrm{Al}-\mathrm{melt}}$, although lower than $\mathrm{T}_{\mathrm{O} 2}$ and $\mathrm{T}_{\text {oxidizer-melt }}$ of the corresponding oxysalts. These results indicate that the limiting initiation step of the reactive thermites is the capability of $\mathrm{Al}$ atoms to diffuse through the $\mathrm{Al}_{2} \mathrm{O}_{3}$ shell towards the reactive oxygen at the interface (gaseous or molten), whereas the limiting initiation step of the less reactive thermites is the decomposition or melting of oxysalts to deliver oxygen to the molten Al. Use of nano-carbon-fueled oxysalt thermites confirm that there are two reaction mechanisms for these oxysalt-containing thermites. In terms of the various ignition dependence of heterogeneous solid-gas reaction or condense state reaction, we proposed a general framework of ignition mechanisms for different oxysalt-containing thermites.

\section{Acknowledgements}

458 Financial support from DOD/DTRA (BRBAA08-Per5-H-2-0065) and the Army Research Office. 459 Garth Egan for his thoughts and discussions on ignition mechanisms.

\section{References}

462 [1] H. Goldschmidt, Iron Age 82 (1908) 232.

463 [2] E.L. Dreizin, Prog. Energ. Combust. Sci. 35 (2009) 141-167.

464 [3] R.A. Yetter, G.A. Risha, S.F. Son, Proc. Combust. Inst. 32 (2009) 1819-1838.

[4] D.G. Piercey, T.M. Klapotke, Centr. Euro. J. Energ. Mater. 7 (2) (2010) 115-129.

[5] X. Zhou, M. Torabi, J. Lu, R. Shen, K. Zhang, ACS Appl. Mater. Interfaces 6 (2014) 30583074. 
[6] Y. Li, J. Yao, Y. Liu, Surf. Coat. Technol. 172 (2003) 57-64.

[7] E.B. Motlagh, J.V. Khaki, M.H. Sabzevar, Mater. Chem. Phys. 133 (2012) 757-763.

[8] P. Lynch, H. Krier, N. Glumac, Proc. Combust. Instit. 32 (2009) 1887-1893.

[9] J.C. Poret, A.P. Shaw, C.M. Csernica, K.D. Oyler, J.A. Vanatta, G. Chen, ACS Sustainable Chem. Eng. 1 (2013) 1333-1338.

[10] K. Jayaraman, K.V. Anand, S.R. Chakravarthy, R.Sarathi, Combust. Flame 156 (2009) 1662-1673.

[11] J. Bouillard, A. Vignes, O. Dufaud, L. Perrin, D. Thomas, J. Hazard. Mater. 181 (2010) 873-880.

[12] B. Siegert, M. Comet, D.Spitzer, Nanoscale 3 (2011) 3534-3544.

[13] L. Menon, S. Patibandla, K. Bhargava Ram, S.I. Shkuratov, D. Aurongzeb, M. Holtz, J. Berg, J. Yun, H. Temkin, Appl. Phys. Lett. 84 (23) (2004) 4735-4737.

[14] C.E. Aumann, G.L. Skofronick, J.A. Martin, J. Vac. Sci. Technol. B 13 (1995) 1178-1183.

[15] A.N. Pivkina, Y.V. Frolov, D.A. Ivanov, Combust. Exp. Shock Waves 43 (2007) 51-55.

[16] A.B. Morgan, J. Douglas Wolf, E.A. Guliants, K.A. Shiral Fernando, W.K. Lewis, Thermochim. Acta 488 (2009) 1-9.

[17] Y. Li, R.K. Kalia, A. Nakano, P. Vashishta, J. Appl. Phys. 114 (2013) 134312.

[18] K. Zhang, C. Rossi, P. Alphonse, C. Tenailleau, S. Cayez, J-Y. Chane-Ching, Appl. Phys. A 94 (2009) 957-962.

[19] F. Severac, P. Alphonse, A. Esteve, A. Bancaud, C. Rossi, Adv. Funct. Mater. 22 (2012) 323-329.

[20] J.Y. Ahn, W.D. Kim, K. Cho, D. Lee, S.H. Kim, Powder Technol. 211 (2011) 65-71.

[21] J.J. Granier, M.L. Pantoya, Combust. Flame 138 (2004) 373-383.

[22] M.A. Trunov, M. Schoenitz, E.L. Dreizin, Combust. Theory Modelling 10 (4) (2006) 603623.

[23] A. Rai, K. Park, L. Zhou, M.R. Zachariah, Combust. Theory Modelling 10 (5) (2006) 843859.

[24] M. Schoenitz, B. Patel, O. Agboh, E.L. Dreizin, Thermochim. Acta 507-508 (2010) 115122.

[25] S. Chowdhury, K. Sullivan, N. Piekiel, L. Zhou, M.R. Zachariah, J. Phys. Chem. C 114 (20) (2010) 9191-9195.

[26] V.I. Levitas, B.W. Asay, S.F. Son, M. Pantoya, Appl. Phys. Lett. 89 (2006) 071909. 
[27] V.I. Levitas, B.W. Asay, S.F. Son, M. Pantoya, J. Appl. Phys. 101 (2007) 083524.

[28] V.I. Levitas, M. Pantoya, B. Dikici, Appl. Phys. Lett. 92 (2008) 011921.

[29] M.L. Pantoya, J.J. Granier, Propellants Explo. Pyrotech. 30 (2005) 53-62.

[30] G. Jian, S. Chowdhury, K. Sullivan, M.R. Zachariah, Combust. Flame 160 (2013) 432-437.

[31] K. Sullivan, M.R. Zachariah, J. Propul. Power 26 (3) (2010) 467-472.

[32] S.W. Dean, M.L. Pantoya, A.E. Gash, S.C. Stacy, L.J. Hope-Weeks, J. Heat Transfer 132 (2010) 111201.

[33] J.Z. Wen, S. Ringuette, G. Bohlouli-Zanjani, A. Hu, N.H. Nguyen, J. Persic, C.F. Petre, Y.N. Zhou, Nanoscale Res. Lett. 8 (2013) 184

[34] K.T. Sullivan, W.A. Chiou, R. Fiore, M.R. Zachariah, Appl. Phys. Lett. 97 (13) (2010) 133104.

[35] K.T. Sullivan, N.W. Piekiel, C. Wu, S. Chowdhury, S.T. Kelly, T.C. Hufnagel, K. Fezzaa, M.R. Zachariah, Combust. Flame 159 (2012) 2-15.

[36] N.W. Piekiel, G.C. Egan, K.T. Sullivan, M.R. Zachariah, J. Phys. Chem. C 116 (2012) 24496-24502.

[37] N.W. Piekiel, L. Zhou, K.T. Sullivan, S. Chowdhury, G.C. Egan, M.R. Zachariah, Combust. Sci. Technol. 186 (2014) 1209-1224.

[38] R. Thiruvengadathan, A. Bezmelnitsyn, S. Apperson, C. Staley, P. Redner, W. Balas, S. Nicolich, D. Kapoor, K. Gangopadhyay, S. Gangopadhyay, Combust. Flame 158 (2011) 964978.

[39] W.K. Lewis, B.A. Harruff, J.R. Gord, A.T. Rosenberger, T.M. Sexton, E.A. Guliants, C.E. Bunker, J. Phys. Chem. C 115 (2011) 70-77.

[40] S. Umbrajkar, M.A. Trunov, M. Schoenitz, E.L. Dreizin, Propul. Explo. Pyrotech. 32 (2007) $32-41$.

[41] M.A. Machado, D.A. Rodriguez, Y. Aly, M. Schoenitz, E.L. Dreizin, E. Shafirovich, Combust. Flame 161 (2014) 2708-2716.

[42] R.W. Armstrong, B. Bschung, D.W. Booth, M. Samirant, Nano Lett. 3 (2003) 253-255.

[43] A.N. Pivkina, Y.V. Frolov, D.A. Ivanov, Combust. Exp. Shock Waves 43 (2007) 51-55.

[44] C. Wu, K. Sullivan, S. Chowdhury, G. Jian, L. Zhou, M.R. Zachariah, Adv. Funct. Mater. 22 (2012) 78-85.

[45] K.T. Sullivan, N.W. Piekiel, S. Chowdhury, C. Wu, M.R. Zachariah, C.E. Johnson, Combust. Sci. Technol. 183 (2011) 285-302. 
2

3 534 535 9743-9746. 11846. U.K., 2001. 14275. 1215.

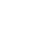
. .

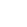

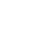

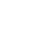
.

[46] C.R. Becker, S. Apperson, C.J. Morris, S. Gangopadhyay, L.J. Currano, W.A. Churaman, C.R. Stoldt, Nano Lett. 11 (2011) 803-807.

[47] G. Jian, J. Feng, R.J. Jacob, G.C. Egan, M.R. Zachariah, Angew. Chem. Int. Ed. 52 (2013)

[48] A. Prakash, A.V. McCormick, M.R. Zachariah, Nano Lett. 5 (7) (2005) 1357-1360.

[49] A. Prakash, A.V. McCormick, M.R. Zachariah, Adv. Mater. 17 (7) (2005) 900-903.

[50] W. Zhou, J.B. Delisio, X. Li, L. Liu, M.R. Zachariah, J. Mater. Chem. A 3 (2015) 11838-

[51] P.R.N. Childs, Practical Temperature Measurement, Butterworth Heinemann, London,

[52] L. Zhou, N. Piekiel, S. Chowdhury, M.R. Zachariah, J. Phys. Chem. C 114 (2010) 14269-

[53] K.H. Stern, High Temperature Properties and Thermal Decomposition of Inorganic Salts with Oxyanions, CRC Press, Boca Raton, FL. 2007, p. 66.

[54] K.H. Stern, High Temperature Properties and Thermal Decomposition of Inorganic Salts with Oxyanions, CRC Press, Boca Raton, FL. 2007, p. 148.

[55] M.E. Hagerman, V.L. Kozhevnikov, K.R. Poeppelmeier, Chem. Mater. 5 (9) (1993) 1211 - 